\title{
Importance of Punctuation Marks for Writing and Reading Comprehension Skills
}

\section{Fatma Suliman $^{1}$ Manal Ben- Ahmeida Salma Mahalla}

Faculty of Arts - Misurata University

Received: 12-3-2019 Accepted: 14-6- 2019 Available Online: 19-6- 2019

https://doi.org/10.36602/faj.2019.n13.06

\begin{abstract}
This study aims to highlight the causes behind the misuse of punctuation marks in order to help Libyan students reduce committing less mistakes in both skills writing and reading. In addition, this current study investigates the relationship between writing and reading in terms of punctuations, it is restricted only to punctuation marks, not all the cohesive devices. A writing test and a reading passage is formulated to test Libyan university students' ability in using punctuation marks as well as an interview is conducted to collect more accurate data. In this research paper, the participants are chosen according to Solven's formula using the qualitative descriptive study, results of this study, could provide solutions that may help to overcome punctuation problems, which many EFL students of the English Department, Faculty of Arts Misurata University face. Finally, the findings refer to the fact that Libyan students do suffer from dealing with punctuation mechanics continuously. Moreover, these findings can be used by teachers to improve students' ability to acknowledge the effective use of punctuations and reduce their problem of misusing punctuation marks in both skills writing and reading. On the light of the findings, it is clear that they committed a large number of remarkable errors progressively, yet in this study, having students become aware of their punctuation mistakes, would possibly enhance and help students to improve their capability to write and read committing less errors. Additionally, their educational motivation and interaction have been turned out extremely higher.
\end{abstract}

Key Words: Punctuation Marks, Reading Comprehension, Writing Skills

${ }^{1}$ f.suliman@art.misuratau.edu.ly

https://misuratau.edu.ly/journal/arts 


\section{أهمية استخدام علامات الترقيم في تطوير مهارات القراءة والكتابة}

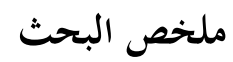

تحدف هذه الدراسة إلى التركيز على الأسباب التي تحد من استخدام علامات الترقيم عند تدريس اللغة الإنجليزية للطلبة في مهارتي القراءة والكتابة، وتأثير عدم الاكتراث همذه

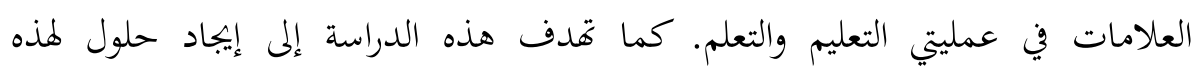
المشكلة. وينحصر هذا البحث في عرض علامات الترقيم فقط وعلاقتها بمهارتي القراءة والكتابة، ولا يتطرق لدراسة أدوات الوصل والربط. ولتحقيق أهداف البحث، تم تطبيق

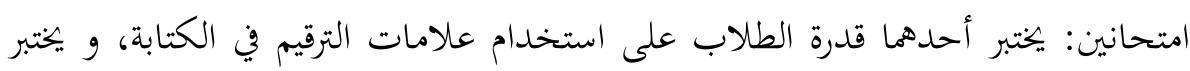
الآخر قدرات الطلاب عند قراءة نصوص لاكتشاف هذه الفواصل، كما تم إجراء مقابلات شخصيه مع عينات من الطلبة لاختبار معرفتهم وقدرقم على استخدام علامات الترقيم، وقد تم اختيار المتطوعين في هذه الدراسة وفقا للصيغة المتبعة في دراسة سلفن بمعطيات نوعيه ووصفيه بما في ذلك إجراء الاختبارات والمقابلات وعرض الإحصائيّات والنتائج .

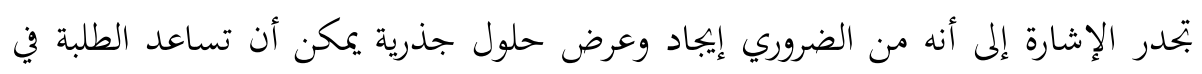
حل مشكلة الاستخدام الخاطئ لعلامات الترقيم، وكيفية استخدامها الاستخدام الأمثل . لمان. الكلمات الرئيسية: علامات الترقيم، الاستيعاب المقروء، مهارات الكتابة.

\section{Introduction:}

\subsection{Research Problem}

Punctuations have a crucial role in language learning; they are ignored and neglected to be taught or learned by many Libyan language teachers and students; therefore, there is a need for more attention to be provided especially, when teaching both reading and writing skills. Punctuations are considered signals used to guide the reader through the text and makes comprehension easier. According to 
Oxford Advances Learner's Dictionary (2000), punctuations are defined as the marks or signs used in writing to separate sentences or phrases. However, different punctuation marks are used in different situation, but all help to convey the message with clarity. As well as, to strengthen the argument and to achieve unity to the text. Therefore, the lack or incorrect usage of punctuation marks in writing and reading, will lead to misunderstanding the message and will be overwhelming for the writer and the reader. Reading and writing are the two skills that are deeply related activities of language, and punctuation is a tool, or rather a basic tool to have effective writing or reading. If a piece of writing has all the information that it needs and all the information can be there with a misused punctuation, the reader definitely will be confused and will face difficulties in understanding the message. To illustrate, it is clear that, if not used correctly, poor punctuation marks make the text challenging and difficult to the reader. "Proper punctuation is both the sign and the cause of clear thinking "(Truss, 2003, p.202).

Several studies have identified the common causes of incorrect usage of punctuation marks (Ahmad, Corbett, Rodgers and Sussex 1995; Rivers, 1981 and Woods, 2006). The findings of these studies, prove the reason behind incorrect usage of punctuation can be traced back to education concept and the lack of familiarity with met discourse function of punctuation marks. In addition, it was found that a number of cohesive devices that contribute to providing the textual integrity affect the continuity in written scientists' discourse. Whereas, this current study is going to investigate the relationship between writing and reading in terms of punctuation, it will be restricted to only punctuations and not the cohesive devices. It is for those reasons the researchers aim to identify the causes of misusing punctuation marks in writing and reading. And provide solutions that may help to overcome this problem, which many EFL students of Faculty of Arts face. The participants are chosen from three semesters in the English Department (Second, Fourth, Eighth) enrolled in the Fall and Spring semesters of Academic year 2017-2018.The number of participants 
depend on whom is willing to volunteer and be tested. However, the researchers will use random design to measure the participants number. Furthermore, a test will be used to examine their potential in using punctuation marks in writing and an interview participant to identify their reading comprehension skills in relation to punctuations. Specifically, it seeks to answer the following questions:

1- How may the causes of incorrect punctuation marks usage in reading and writing by the participants be described?

2- What are the supporting effects that certain reading passage may add in using correct punctuation marks?

3- -How can the students achieve cohesion irrespective of the language they use while reading a passage?

\subsection{Hypotheses}

Based on the reviewed literature and studies, it is hypothesize that there is a need by students for more attention practicing punctuations in writing and reading. It is also hypothesized the reason behind incorrect usage of punctuation marks, is that students do not have full grasp of the correct usage of them and this could be because of lack of doing English readings. However, some acknowledge the rules but when it comes to practice they do not apply them. Moreover, the findings will be used to improve students' punctuations in Writing I, II and Academic Writing and Reading Comprehension courses.

\section{Review of Related Literature}

\subsection{Reading Skill and Punctuations}

Reading plays an important role in language learning; it is more than knowing words and grammar." Reading is the most important activity in any language class, not only as a source of information and a pleasurable activity, but also as a means of consolidating and extending one`s knowledge of the language" (Rivers,1981, p.259). Reading is an interactive process between the writer and the reader and it is a means of communication and sharing information and ideas. 
It is described by Alderson (2000) as interpreting means interacting to a written text as a piece of communication. Moreover, many believe that it is a mental process, so it needs other skills to be combined with such as: writing, speaking and listening (Graham \& Berin,2007; Alderson (2000); (Rivers,1981). Harmer (1998) underlines that "Reading texts also provide opportunities to study language: vocabulary, grammar, punctuation, and the way they construct sentences, paragraphs and texts "(p.68).

\subsection{Writing and its Relation to Punctuations}

Writing is an important tool of learning subject matters and it is a tool of extending and deepening knowledge. Jozsef (2001), states that writing is the most complex human activities. It involves the development of design ideas, experiences with subjects, and the capture of mental representation of knowledge. Writing is not about group of letters or sentences, it is about writing in a right way using different vocabulary, grammar and punctuation. Graham and Berin (2007), states that writing plays distinct roles: It is a skill that draws on subskills and processes such as handwriting and spelling; a rich knowledge of vocabulary; mastery of the conventions of punctuation, capitalization, word usage, and grammar; and the use of strategies such as planning, evaluating, and revising text (p.23). In 2000, Danielson (cited in Naeem 2007) defines, mechanics as "standard writing conventions such as spelling, punctuations, capitalization, and sentence structure skills". Besides, formatting correct grammar, punctuation, spelling, and sentence structure are essential components of scholarly writing. In addition, punctuations are very crucial, because if the writing is not well written, many educated readers will not even bother to read it, either because it is too difficult what the author is trying to state, or they will just assure that it will not be good as it does not appear to be well written. A proof of that could be the correct use of punctuation marks and how they cut the steam of words into meaningful groups and prevent confusion (Robert, 2006). 


\subsection{Punctuations in Reading and Writing}

Writing and reading are quite similar and closely related. Some would say, better writers tend to be better readers, and better readers produce better writing. "Writing is sometimes seen as the 'flip side' of reading. It is often assumed that adolescents who are proficient readers must be proficient writers"(Graham \& Perin,2007, p.7). Reading is the ability to use the symbols of writing system, the experience and knowledge between reading and writing, can strength a reader ability to write and a writer to read. Both of them are not contrary processes, they rely on similar cognitive mechanisms that allow for simultaneous growth as well as transfer of knowledge. The two skills reading and writing are considered to be related activities and they totally complete each other. In both of writing and reading, punctuations stand as an essential tool in conveying the message. They help the writer and reader to make sense of a text, and they make what is composed clear and easy to read. Allen (2002), assumes that punctuations have useful purpose for having whatever kind of writing clear and easy to understand. And if a text is laid out correctly, it will be considered as a strong piece of writing. On the other hand, poor punctuations can cause complications for both of the reader and writer, they can change the meaning of a text. Moreover, in speaking, humans use body language, pauses and gestures to clarify the message. In writing, punctuations such as commas, colons and dashes help to know the exact meaning and provide most of these interpretation clues. And they are signals to the reader that indicate place emphasis, pauses, and show the relationship between the element of a text.

\subsection{Presenting Punctuation Marks}

Punctuation marks are a basic role in the interpretation of a certain text, and to help the reader to understand the message clearly. Therefore, using them incorrectly leads to misunderstanding the message. Lukeman (2011), states that punctuations are like the music 
of a writing text. As the maestro could affect the practicality of a song by manipulating its rhythm, punctuations could do so for reading experience, highlighting the optimum in a written passage. Therefore, they are symbols that are used in various languages to organize sentence structure, to indicate the vocal rhythm and emphasis of words, phrases as well as sentences. Writing is all about communicating ideas; each sentence consists of a complete thought which the writer aims to communicate in his/her style of writing to readers and in turn they have to understand. Nevertheless, the audience will not understand that chunk if they could not figure out where it begins and where it ends, and so this is what punctuations are for. In Oxford Advanced Learner's Dictionary (2000), punctuations are defined as the marks or signs used in writing to separate sentences or phrases. Likewise, when punctuations are correctly used, they lead the reader through the text and makes a text more understandable. Moreover, they can help to strengthen the text and change the meaning of a sentence. Some proper punctuations work on a subconscious level. They direct the reader to the exact meaning without becoming too curious (Woods, 2006). In addition, Allen (2002), adds that punctuations have two levels: At sentence or phrase level, marking out structure and at the word level, linking or separating individual words. As well as there are two roles in relation to these levels: To separate sentences or separate parts of sentences and to link groups of words into one sentence. There are very important and essential punctuations that Libyan teachers should not ignore and inform students with, especially when teaching writing and reading.

\subsection{Functions of Punctuation}

Without punctuation marks, many sentences are mere disorders of words. In 2012, Awad explains that there are three functions for punctuation marks in English and they are as the following: first, Phonetic function: This function is very significant as punctuation marks indicate obviously the rhythm, pauses, and tone inflexions in a 
written document; a written document has a tone. Connelly (2005 cited in Awad 2012) that the tone is controlled by commas, semicolons, colons, points of ellipsis and so on. Many times, the tone is neglected, and readers are free to interpret that tone in the way they understand and that may lead to misunderstanding. In this respect, punctuation marks are like traffic lights telling us to slow down and stop. Second, Grammatical function: Punctuation marks are utilized in direct style like to mark emphatic content, to form interrogations, to emphasize syntactic elements displaced from their natural positions, and to frame the structure of the sentences, complex sentences, paragraphs and so on. Third, Semantic Function: By means of punctuation, readers are enabled to comprehend exactly the transmitted meaning which was intended by the writer and to understand the significance of particular words/phrases by highlighting them differently than ordinary text, utilizing italics, underlining, bolds, capitals, etc.

\subsection{Arab Learners' Punctuation Errors in English.}

Without punctuation marks, several sentences are just a combination of words could not transmit the desired meaning. English rules of punctuation marks vary from the Arabic punctuation rules; therefore, many students commit many errors regarding this field. In 2012, Awad has found that the most common errors among Palestinian University students were the overuse of comma at the expense of the period, the incorrect use of the capital letter, the wrong use of the quotation marks and the misuse of semicolon respectively.

Abbreviations: They are shortened forms of words or phrase like the word Prof. for the word professor. Abbreviations are commonly used in business communication and technical writing. Almost all abbreviations are formed from a letter or group of letters taken from the original word. In a scholastic paper, abbreviations are rarely used to stand in for major concepts or terms. Rather, they are usually shortened forms of commonly used but moderately minor words, like 
Dr. for doctor. Most are common enough that a writer does not need to provide the reader with an extended definition.

Capitalization: It is when the uppercase style is adopted. The function of capitalization is to emphasize words or to show their importance. There are some rules for capitalization. First, writers capitalize the first word of a sentence, because it marks the beginning of a new idea and indicates its importance too. Furthermore, it is applied with proper nouns and titles.

Hyphenation: It is the splitting of words into smaller units. It is used mainly to help the reader and to avoid ambiguity. The main aim of hyphenating a term is to prevent confusion on the part of the reader. Though some hyphenated words are found in the dictionary, others are simply formed by convention. Therefore, hyphenation is used chiefly to make the reader follow what has been written easily.

\subsection{Definition of Errors}

Errors are typically produced by learners who do not yet have fully command of language system; they arise due to the imperfect competence in the target language. Chomsky (1998), confirms that errors are inevitable and a fundamental stage of learning. They are noticeable verification that learning is occurring. In 1981, Corder clarifies that there is a distinction between a mistake and an error. $\mathrm{He}$ states that the mistake which is a performance error due to arbitrary speculation or slip and the error which pertains characteristic in the learner's interlanguage reveal the learner's system of operation while learning. There are two predominant sources of errors, namely, interlingual errors and intralingual errors (Brown, 2000).

Interlingual Error: Interference, language transfer, and crosslinguistic interference are also known as interlingual errors. In 1981, Corder explains that these types of errors occur when the learner's habits; patterns, systems, or rules, interfere or prevent him or her, to some extent, from learning the structure and rules of the second language. Foreign language learners tend to transfer some of their 
native language rules to express their needs in the foreign language. Furthermore, Brown (2000 cited in Jannat, 2014), clarifies that the greatest learners' errors in the second language arise mainly from their assumption that the second language forms are similar to their native language. There are two kinds of language transfer, the positive and negative one. According to Ellis (1994), positive transfer happens when there is some likeness among the learner's native language and second language. However, negative transfer occurs when there are dissimilarities between the learner's first language and second language (as cited in Jannat, 2014). Intralingual Error: Interference from the student's own language is not the only reason for making errors. Students may commit some errors in the target language, since they are not fully equipped with its rules. , Intralingual errors can be defined as the sophistication that the learner encounters when confronting patterns of a new language system, irrespective of how the target language patterns may appear differently in relation to the learner's mother tongue. Therefore, they are not related to the first language transfer, yet they contributed by the target language itself.

\subsection{Punctuations Change the Meaning}

It deducted that punctuations serve as an important tool in writing and help the reader to understand the message easily. On the other hand, missing or overused them can change the meaning unintentionally and confuse the reader. Misplaced or insufficient punctuations create ambiguity as well. " Proper punctuation is both the sign and the cause of clear thinking "(Truss, 2003, p.202). Moreover, punctuations are vital to disambiguate the meaning of a sentence. So, punctuations can make a big difference in the meaning of whatever the writing or the reading is. The writer should pay more attention to them and not to use them randomly. And the reader should learn for what reason they exist so he/she can use them appropriately.

\subsection{Common Punctuation Marks}

\begin{tabular}{l|l|l}
\hline Kinds & Symbol & Uses
\end{tabular}




\begin{tabular}{|c|c|c|}
\hline $\begin{array}{l}\text { Full stop } \\
\text { Period }\end{array}$ & $()$. & $\begin{array}{l}\text {-To end up a sentence } \\
\text {-For abbreviations } \\
\text {-Website addresses }\end{array}$ \\
\hline Comma & $()$, & $\begin{array}{l}\text {-When listing items in a sentence } \\
\text {-To separate words or phrases of three or more } \\
\text {-With coordinate conjunctions (for, and, nor, } \\
\text { but, yet, or, so) } \\
\text { With an introductory phrase to set }\end{array}$ \\
\hline $\begin{array}{l}\text { Question } \\
\text { Mark }\end{array}$ & $(?)$ & $\begin{array}{l}\text {-To get information } \\
\text {-After each question in a series even if the } \\
\text { question is not a complete sentence } \\
\text {-After a rhetorical question } \\
\text { - At the end of a tag question }\end{array}$ \\
\hline $\begin{array}{l}\text { Exclamation } \\
\text { Mark }\end{array}$ & $(!)$ & At the end of exciting sentences \\
\hline Semicolon & $(;)$ & $\begin{array}{l}\text {-To join two related sentences with conjunctive } \\
\text { adverbs } \\
\text {-To connect items in a list if there are already } \\
\text { commas in the sentence }\end{array}$ \\
\hline Colon & $(:)$ & $\begin{array}{l}\text {-To emphasize whatever introduced } \\
\text { - After a salutation of a formal letter }\end{array}$ \\
\hline $\begin{array}{l}\text { Quotation } \\
\text { Marks }\end{array}$ & ( " " ") & $\begin{array}{l}\text {-To quote exact words from spoken or written } \\
\text { language } \\
\text {-To show that a word or phrase is used } \\
\text { unusually } \\
\text { To show titles }\end{array}$ \\
\hline Parentheses & $(\quad)$ & -To enclose information that can be left out \\
\hline Brackets & [ ] & $\begin{array}{l}\text { To explain the original text by an editor, } \\
\text { editorial comments }\end{array}$ \\
\hline Braces & \{\} & More common in mathematics and science \\
\hline Ellipsis & $(\ldots)$ & $\begin{array}{l}\text {-To show an omission in a quote } \\
\text {-To shorten the quote without changing the } \\
\text { meaning } \\
\text {-To indicate a pause in a thought } \\
\text {-To create suspense }\end{array}$ \\
\hline Apostrophe & $(')$ & $\begin{array}{l}\text {-To indicate possession by a noun } \\
\text {-To represent missing letters in a contraction }\end{array}$ \\
\hline Slash & $(/)$ & $\begin{array}{l}\text {-To separate parts of websites } \\
\text {-To write dates } \\
\text {-To show the word or and the word per in a }\end{array}$ \\
\hline
\end{tabular}




\begin{tabular}{|l|l|l|}
\hline & & $\begin{array}{l}\text { measurement } \\
\text {-To separate lines of a poetry or rhymes in a } \\
\text { regular text }\end{array}$ \\
\hline Hyphen & $(-)$ & $\begin{array}{l}\text {-To connect the part of a compound word } \\
- \text { To connect split words such as numbers and job } \\
\text { titles } \\
\text {-When dealing with some prefixes }\end{array}$ \\
\hline En Dash & $(-)$ & $\begin{array}{l}\text {-To show a range of numbers } \\
\text {-To show a period of time } \\
\text {-To show distance } \\
\text {-To illustrate game scores }\end{array}$ \\
\hline Em Dash & $(-)$ & $\begin{array}{l}\text {-It is used in informal writing to create a break } \\
\text { in a sentence } \\
\text {-To show a sudden change of thoughts }\end{array}$ \\
\hline
\end{tabular}

\subsection{Related Studies}

In the study conducted by Ahmet (2010) "Prospective teachers: in (2012) this related study aimed at investigating how problematic these punctuation marks can be and to what extent the students' familiarity with their met discourse and pragmatic functions can affect their translation from English to Persian. He believes that the minority of students were successful and the majority of them were poor and that because of the root of their poor performance can be traced back to the lack of contrastive study on punctuation systems of English and Persian as well as lack of familiarity with met discourse functions of punctuation marks. This recent research attempts to look into how punctuation marks have pragmatic and semantic load and can be problematic in translation. while, this research studies the relationship between writing and reading in punctuation marks and how they change the meaning. Both studies are similar in the importance of punctuation marks.

The last related study is "Punctuation of Cohesive Devices" conducted by Tatiana and Tatiana (2014) This study shown the use of punctuation marks does not always comply with the rules and the classification of cohesive devices. The findings showed a number of 
cohesive devices that contribute to providing the textual integrity affect the continuity in written scientists' discourse. The most common discourse markers, or conjunctive adverbs are the following, thus, therefore, hence, for example, however, finally, moreover, consequently, for instance, on the other hand, nevertheless, then. This research studies the importance of cohesion in a scientific text by the choice of cohesive devices and their usage. This research is similar to the recent research that the punctuations made the text coherent.

\section{Method}

\subsection{Research Design}

The current study follows the qualitative design to identify the causes of misusing punctuation marks in writing and reading of students who are enrolled in Writing I, II, and Academic Writing courses and Reading Comprehension course. The qualitative method is used to provide a better understanding of the research problem and to validate the findings of the research.

\subsection{Participants and Setting}

The participants are the students enrolled in Writing courses and Reading Comprehension course in the Fall and Spring semester of academic year 2017 - 2018. The number of students of both genders is chosen according to random design to contribute in the test or interviews. The research is conducted in the English Department, Faculty of Arts, Misurata University in Misurata, Libya. The total number of participants is one hundred of both genders divided according to the courses they have joined. Twenty-five participants in Writing I course, thirty in Reading Comprehension course, twenty in Writing II course and twenty-five in Academic Writing course.

\subsection{Research Instrument}

In order to accomplish the findings of this research, the researchers applied a test and an interview placed on pages 17 and 18 . Significant findings for this study are based on a test and interviews 
designed by the researcher. The test and the interviews identify the causes of misusing punctuation marks in writing and reading. This study is carried out to discover the main reasons for most common errors committed in punctuations from the participants' point of view.

\subsection{Procedure: Data Collection and Data Analysis}

The researcher secured all the necessary permissions from authorities in the conduct of the study. The test served as the main source of data for this research. It was given to students of Writing class. They are given between 30 and 45 minutes to accomplish the test. After that, there was an interview for volunteer students to determine their ability to use punctuation marks in reading. Qualitative data were used in this research to answer the research questions.

\subsection{Ethical consideration}

Participants were informed about their confidentiality, anonymity, and right to withdraw from participation. A letter was given to inform them that this activity will in no way affect their performance or grades in the said course.

\section{Sample of The Test Used}

Fill in the blanks with the appropriate punctuation mark in the following sentences.

Comma (,), Period (.), Semicolon (;), Question mark (?), Colon (:), Quotation marks (" "), Exclamation marks (!), Brackets (()), Dash (_) and Hyphen (-).

1) How do you feel today...

2)What a big foot you have...

3) Due to the fact that he neglected the children... they became disobedient...

4) ...what is the time now......Asked Fatima... 
5) Please bring the following items with you...a bank card... a bank statement and your passport...

6) We visited several European countries... England... France... Spain... on our trip last year...

7) I expected a package this morning... however... I waited all the day for it to arrive...

8) John said... ... I really hate when it's hot outside... ...

9) The professor was unwilling to change the due date... even for a candy bar...

10) Dr. Jill Stein is not a well...known presidential candidate...

11) As soon as the guests had gone... she rushed to the telephone...

12) I love fiction stories...

13) I drive near the president...s house every day.

\section{Sample of The Reading Passage Used}

The reading passage below was introduced to the thirty participants enrolled in the Reading Comprehension course. They were asked to read it paying attention to how the punctuation marks are placed.

\section{Alice's Adventures in Wonderland}

Alice was beginning to get very tired of sitting by her sister on the bank, and of having nothing to do: once or twice she had peeped into the book her sister was reading, but it had no pictures or conversations in it, "without pictures or conversations?"

So, she was considering in her own mind (as well as she could, for the hot day made her feel very sleepy and stupid) whether the pleasure of making a daisy-chain would be worth the trouble of getting up and picking the daises, when suddenly a White Rabbit with pink eyes ran close by her. 
There was nothing so very remarkable in that; nor did Alice think it is very much out of the way to her the Rabbit say to itself, "O dear! O dear! I shall be too late!" ( when she thought it over afterwards, it occurred to her she ought to have wondered at this, but at the time it all seemed quiet natural); but when the Rabbit actually took a watch out of its waist-pocket, and looked at it, and then hurried on, Alice started to her feet, for it flashed across her mind that she had never before seen a rabbit with either a waistcoat-pocket, or a watch to take out of it, and burning with curiosity, she ran across the field after it, and fortunately was just in time to see it pop down a large rabbithole under the hedge. In another moment down went Alice after it, never once considering how in the world she was to get out again.

\section{Discussion and Results}

\subsection{Part one: Textual Observation}

A textual analysis of data is presented. Three semesters were observed on their ability in using punctuation marks in writing and reading. Twenty-five students enrolled in Writing I course were randomly chosen. When testing their ability in using punctuation marks in writing, it was found out that most of the students were poor in writing as they were not familiar with most of the punctuation marks such as, (Brackets, Quotation marks, Colon, Semicolon and Hyphen) and the punctuation marks that they knew (Question mark, apostrophe, Exclamation mark, period and Comma in some sentences). In terms of a comma, three students were good like in the following example: We visited several European countries (England, France, Spain, on our trip last year. But when it came to using a comma after a linking word and reported speech, they failed to use it correctly. For example, I expected a package this morning; however, I waited all day for it to arrive.

Table one: A sample of two examples conducted by first semester students using commas.

\section{Course No. of students Already Not used}




\begin{tabular}{|c|c|c|}
\hline observed & & used \\
\hline Writing I & 22 out of 25 & $\begin{array}{l}\left(; !-_{-}(): "\right. \\
")\end{array}$ \\
\hline Writing I & 3 out of 25 & $\begin{array}{l}\text { Good use of commas } \\
\text { but not after linking } \\
\text { words }\end{array}$ \\
\hline
\end{tabular}

Overall, observing students' results of their ability in using punctuation marks, they were not familiar with using commas, periods, apostrophes and question marks. It seems that such a result obtained because of being at the beginner level and they did not specialize in English in the secondary school, which means their background is not English language. Looking at the second semester students, fourteen out of twenty students were tested in writing and reading in terms of punctuation marks. However, it was observed that they were better than the first semester students. Regarding Writing II, it seems that fourteen out of twenty accomplished the test in an unexpected way while six of them did not. In addition, they were familiar with some of the punctuation marks that the first semester students were not familiar with, such as (quotation marks and hyphens) . However, they did not know the rules of (semicolon, colon, brackets and dash). When reading, it was noticed that four out of thirty students were good in following the question marks as in the following example, "without pictures or conversations?" twenty six of them changed the tone of their voices and they used the rule of question mark in an appropriate way, which was surprising, but sometimes they made some pauses. This could have happened because of the difficulty of some words.

Table two: However, second students showed different results when being observed in both Writing II and Reading Comprehension courses. This is illustrated in the table below.

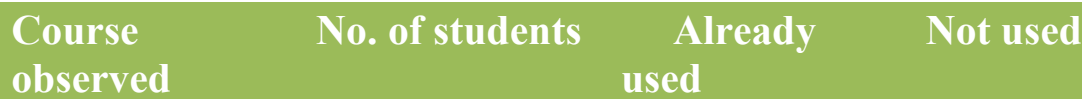




\begin{tabular}{|c|c|c|c|}
\hline Writing II & 6 out of 20 & (?,!!:" ".) & (_( );) \\
\hline Writing II & 14 out of 20 & $(?,)$. & (!,' " ";) \\
\hline Reading & 26 out of 30 & ( ?,!,.." ";) & $\left(:^{\prime}()\right)$ \\
\hline Reading & 4out of 30 & $(?,)$. & $(! ;: "$ " " ') \\
\hline
\end{tabular}

When comparing second semester students to those enrolled in first semester, it can be observed that the first ones were better than the later ones; even though, they were not specialized in English in high school. Never the less, they performed much better than the first semester students. This could be because of the courses that they have taken in the department. Moreover, watching films and listening to music could be another cause as it was the answer of two participants, when they were asked about their good reading. When testing third and fourth semester students, twenty-five students were chosen to test their ability in using punctuation marks in Academic Writing and Reading. In comparison with the other two semesters being studied, they were the best in marking the correct punctuations in both tests of Academic Writing and Reading Comprehension. Twenty-three students were familiar with most of the punctuation marks only, (brackets, colons and dashes). However, it was clear that even if they did much better than the other two samples, they were not professional enough when using punctuation marks, but they were still much better acknowledging them comparing with the two semesters under investigation. They tried to follow the punctuation marks in reading using an accent changing their voice and some expression.

Table three: A sample of two examples conducted by third and fourth semester students using commas

\begin{tabular}{llll|}
$\begin{array}{l}\text { Course } \\
\text { observed }\end{array}$ & No. of students & $\begin{array}{c}\text { Already } \\
\text { used }\end{array}$ & Not used \\
$\begin{array}{l}\text { Academic } \\
\text { Writing }\end{array}$ & 23 out of 25 & $(?$, !:" ". - :;) & $\left({ }_{-}() \ldots\right)$ \\
\hline $\begin{array}{l}\text { Academic } \\
\text { Writing }\end{array}$ & 2 out of 25 & $\left(?,\right.$. , $\left.^{\prime}\right)$ & $\left(!, "\right.$ ": $\left.{ }_{-}() \ldots\right)$ \\
\hline
\end{tabular}




\begin{tabular}{|llll|}
\hline Reading & 25out of 30 & $(?,$, ,." ";) & $($ : ' ( ) ) \\
\hline Reading & 5out of 30 & $(?,)$. & $(! ;$ " " " ') \\
\hline
\end{tabular}

In general, they were the best in using punctuation marks in writing and reading. It seems this result is because they specialized English in the high school or they are advanced in the different courses they have been studying in the department.

Overly, we have noticed that many students do not take full advantages of punctuations, they struggle fear of using them. As well as the most frequent use of punctuation marks from the three semesters was commas, question marks, apostrophes and periods; which no participant feared of using, as they were not familiar using the other forms of punctuations, and some participants were good in using the comma in some sentences and not in others. Meanwhile, some are afraid that if they use other forms of punctuations, they will use them incorrectly. Moreover, some students were good in following the punctuation marks in reading; however, because of the difficulty of pronouncing some words, they failed to use them effectively.

\subsection{Part two: Interview}

The third and fourth semester students were chosen in order to find out whether they know that punctuation marks can change the meaning. Based on the results of the previous test, it was found that students from the first to the seventh semester are not strong enough to know that they still face challenges and difficulties. The result was somehow satisfying, the students of the third and fourth semester knew that punctuations can change the meaning. In this part, six participants from the third and fourth semester were interviewed giving permission to provide their first name only and asked the following questions:

Q1. Do you believe that punctuation marks change the meaning? How? Provide an example where the meaning is changed? 
Aya answered, "yes, punctuations are important and if it is not used correctly, it will change the meaning. One example is:

The student said " the teacher is crazy.

The student, said the teacher, is crazy."

From Aya's answer, it was clear that she has the ability to use punctuations in a good way. She could form sentences with correct punctuations known that the first sentence is said by the student and it was considered a reported speech. However, the second sentence was formed by the student to show that this time it was the teacher who was talking. It is obvious that Aya is very strong in building sentences when it comes to the structure, punctuations and reported speech.

Moreover, Hawa said yes, "I think that punctuation marks sometimes change the meaning. For example:

Most of the times, travelers worry about their luggage.

Most of the times travelers worry about their luggage."

The student understood that there were differences between the first and second sentences, but did not understand how. When we delete the comma of the second sentence, the meaning is totally different.

The third student Khawla provided her answer with the comparison between Arabic and English punctuations and her answer was: "yes, punctuations are very important for good writing and they have a big role in changing the meaning. One example is:

What do you think? am I okay?

What do you think? I am okay."

In the first sentence the question mark show that the speaker asks about her status and the second sentence the speaker says she is fine. Furthermore, this is a very good example because the student thought about their first language and how she would use punctuations when speaking the second language which is English. 
To provide more, Fatima was:" well, yes, it is that punctuations change completely the meaning and sometimes the reader gets a wrong image when it used incorrectly. Such as:

The man dropped the bullet in his mouth.

The man dropped, the bullet in his mouth."

Looking at the first example, the comma changes the whole meaning. The first sentence means that the man put the bullet in his mouth, while the second sentence means when the man fell, the bullet was in his mouth.

The answer of the fifth student Nada was, "Punctuations are essential to meaning and when they are used incorrectly, they convey different meaning to the one that is required. For example:

Let's eat, mum.

Let's eat mum."

In the first sentence the mum is being called for dinner. And the second sentence the mum will be eaten. Here the omission of comma has changed the meaning to complete nonsense.

Mona states "Actually, I am not good when using punctuation marks and this is my problem in the writing skill. I just put them randomly and I never thought of this aspect that punctuations change the meaning." To sum up, third and fourth semester students are strong, capable and qualified to use some of punctuation marks that are very common since they have the ability to differentiate them in forming different examples.

\section{Conclusion}

Overly, punctuations are one of the most important aspects of language learning. They are signs used to clarify the message that is being conveyed in an easy way. Meanwhile, using them incorrectly can change the meaning of the message completely. Punctuation marks play a vital role in writing and reading, that they make what is 
written easy to read and what is read easy to follow and understand. Moreover, writing formally and academically in English is more than choosing the right words in the right order which is very essential to accomplish all the punctuation marks knowing their meaning. Moreover, in order to provide a good piece of writing that definitely will be clear for the reader to understand, as well as it is essential for the students when reading to know how to use them correctly by using pauses and changing the tone of the voice to convey the required meaning to the listener. Specifically, it was noticed by the researchers that most students face difficulty in using punctuation marks during the writing and reading test, and that is because of lack of practice in writing and reading. Particularly, the current study aimed to highlight the causes of misusing punctuation marks in writing and reading and to suggest solutions to overcome this problem. The implication for educators and future research can be significant to Libyan English language teachers and students; it helps to widen their knowledge about punctuation marks, and encourage them improve their ability to master punctuations. Moreover, it can be used as a base for future studies to provide more emphasis on the relationship between writing and reading in terms of punctuations as well as to focus on a number of cohesive devices that contribute to providing the textual integrity, which affects the continuity in written scientists' discourse. Furthermore, practicing punctuation especially in reading is very important. We encourage that students would read more English books such as novels, stories, etc. This could help students use punctuations in writing more effectively, and to acknowledge how to apply each kind correctly. Other cohesive devices are recommended for future research since they are as important for both writing and reading skills.

\section{References}

https://misuratau.edu.ly/journal/arts 
Ahmad, K., Corbett, C., Rogers, M., \& Sussex, R., (1995). Computers, Language Learning and Language Teaching. Cambridge: Cambridge University Press

Alderson, J.C. (2000). Assessing Reading: Cambridge Language Assessmen Series. New work: Cambridge University Press.

Allen, R. (2002). Punctuation: One step ahead. Oxford: Oxford University Press

Awad, A. (2012). The Most Common Punctuation Errors Made by English and the TEFL majors at An-Najah National. University. An-Najah University Journal for ResearchHumanities, 10 (1), 211-233. Retrieved from https://scholar.najah.edu/publication/journal-

Brown, H. D. (2000). Principles of language learning and teaching. White Plains, NY: Longman

Chomsky, N. (1998). Minimalist inquiries: The framework.

Cambridge, MA: Distributed by MIT Working Papers in Linguistics, MIT, Dept. of Linguistics

Corder, S. P. (1981). Error analysis and interlanguage. London: Oxford University Press

Graham, S. \& Perin, D. (2007). Writing next: Effective strategies to Improve writing of adolescent in middle and high Schools. NY: Alliance for excellent education.

Harmer, G. (1998). How to teach English: An introduction to the practice of English language teaching. Essex: Longman

Jozsef, H. (2001). Advanced writing in English as a foreign: A corpus-based study of processes and products. France: The University of Pecs.

Lukeman, N. (2011). The art of punctuation. Oxford: Oxford University Press 
Naeem, M. A. R. (2007) A suggested CALL program to develop EFL college learners' mechanics of writing. Faculty of Education, Kafr El-Sheikh University. Retrieved from https://eric.ed.gov/?id=ED499569.

Oxford advanced learner's dictionary (2000). Oxford: Oxford University Press

Rivers, W.M. (1981). Teaching foreign language skills. Chicago: The University of Chicago press.

Robert, C. (2006). The English style book. A guide to the writing of Scholarly English. University of East Anglia. Norwich The Literary Dictionary.

Truss, L. (2003). Eats, shoots and leaves: The zero tolerance approach to punctuation. London: Profile books.

Woods, G. (2006). Punctuation: Simplified and applied. Canada: Wiley, Hoboken, NJ. www.teachingpacks.co.uk 